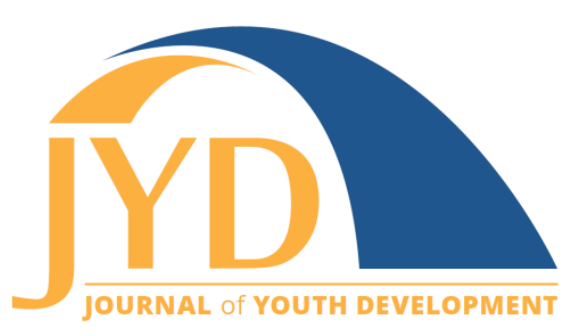

http://jyd. pitt. edu/ | Vol. 13 Issue 3 DOI 10.5195/jyd.2018.646 | ISSN 2325-4017 (online)

\title{
The Balanced Energy Physical Activity (BEPA) Toolkit
}

\section{Barbara Bromley Brody}

Oregon State University

barbara.brody@oregonstate.edu

\section{Katherine B. Gunter}

Oregon State University, College of Public Health and Human Sciences

katherine.gunter@oregonstate.edu

\section{Abstract}

The Balanced Energy Physical Activity Toolkit is an evidence-based, behaviorally focused physical activity resource. The BEPA-Toolkit is designed for applications in various educational settings to increase children's physical activity time, with materials and activity ideas that are applicable for use in and outside of the classroom and before, during, or after school. It includes over 50 activity cards that convey integrated messages about healthy eating and physical activity through movement. This practical resource has been shown to increase children's physical activity at school.

Key words: obesity prevention, physical activity promotion, school-based physical activity

\section{Introduction}

Obesity affects nearly one in five school-age children and young people (ages 6 to 19 years) and has been shown to detrimentally influence positive youth development (Hales, Carroll, Fryar, \& Ogden, 2017). Data from the 2015 Youth Risk Behavioral Survey (YRBS) show that low physical activity, poor diet, and spending too much time being inactive are not only associated with poor health, but also with poor educational outcomes (Raspberry et al., 2017). Thus, the capacity to easily integrate activities that target these behavioral precursors for obesity may be an important addition to youth development programming.

(c) EY New articles in this journal are licensed under a Creative Commons Attribution 4.0 License. This journal is published by the University Library System, University of Pittsburgh and is cosponsored by the University of Pittsburgh Press. The Journal of Youth Development is the official peer-reviewed publication of the National Association of Extension 4-H Agents and the National AfterSchool Association. 
Balanced Energy Physical Activity (BEPA) Toolkit

The Balanced Engergy Physical Activity Toolkit (BEPA, is a low-cost, evidence-based resource developed specifically to support obesity prevention efforts in low-income educational environments. BEPA was originally developed for Extension educators to provide physical activity programming in concert with nutrition education via outreach programs (e.g., SNAP-Ed, 4-H) in elementary school settings. Due to widespread demand for low-cost, obesity prevention resources in school settings outside of nutrition education programming, the BEPA delivery model was modified to a broad-based, train-the-trainer approach. Classroom teachers and other educators such as $4-\mathrm{H}$ youth development specialists receive training to provide programming in a variety of formats that fit their needs.

Examples of BEPA-Toolkit implementation include:

- Extension nutrition educators and 4-H youth development specialists provide integrated healthy eating and physical activity messaging through movement.

- Classroom teachers implement BEPA to provide classroom-based physical activity breaks.

- 4-H Teens as Teachers are trained to use the BEPA-Toolkit to enhance learning and physical activity opportunities for elementary-aged students.

The effectiveness of the BEPA-Toolkit was evaluated in six elementary schools in underresourced communities. This was a rigorous evaluation where children's physical activity at school was assessed through objective monitoring (versus self-report). Outcomes revealed that when teachers use the BEPA-Toolkit, children were more active (Gunter, Abi Nader, \& John, 2015), and the more active children were at school, the less likely they were to be obese (Gunter, Abi Nader, Armington, Hicks, \& John, 2017). The BEPA-Toolkit is currently included in the National Coalition for Childhood Obesity Research and SNAP-Ed Toolkit (2016) of approved obesity prevention resources.

The BEPA-Toolkit includes a tote with portable play items such as beanbags, beach balls, buckets, cones, scarves, chalk, and painter's tape. In addition, there is an activity card pack with guidance cards and 58 unique activities aligned to physical education and health education standards. Other resources include an implementation manual and access to training documents, policy and reporting templates, and for an additional fee, training and support. The approximate cost per kit is $\$ 100$. 


\section{Limitations}

To date the ability of the BEPA-Toolkit to influence educational outcomes has not been tested. That said, sufficient data support that increasing children's physical activity at school leads to numerous positive developmental outcomes including immediately evident benefits to memory, executive function, classroom behavior, and longer term positive effects on academic performance and health (Physical Activity Guidelines Committee, 2018).

\section{Highlights}

- Using the BEPA-Toolkit has promoted physical activity among youth.

- BEPA-Toolkit activities are currently accessible online at no cost, and many activities require no equipment.

- The BEPA-Toolkit is aligned with elementary physical education and health education standards, making it a desirable resource to share with education stakeholders.

For more information about the BEPA Toolkit, including access to activity cards, manual, videos, and contact information, visit http://extension.oregonstate.edu/growhkc/tools/bepa.

\section{References}

Gunter, K. B., Abi Nader, P., Armington, A., Hicks, J. C., \& John, D. (2017). Evaluation of an Extensiondelivered resource to accelerate progress in childhood obesity prevention: The BEPA-Toolkit. Journal of Extension, 55(1), Article 2FEA5. Retrieved from https://www.joe.org/joe/2017april/a5.php

Gunter, K. B., Abi Nader, P., \& John, D. H. (2015). Physical activity levels and obesity status of Oregon rural elementary school children. Preventive Medicine Reports, 2, 478-82.

Hales, C. M., Carroll, M. D., Fryar, C. D., \& Ogden, C. L. (2017). Prevalence of obesity among adults and youth: United States, 2015-2016 [NCHS Data Brief]. 288, 1-8.

Physical Activity Guidelines Advisory Committee. (2018). 2018 Physical Activity Guidelines Advisory Committee scientific report. Washington, DC: U.S. Department of Health and Human Services. Retrieved from https://health.gov/paguidelines/secondedition/report/pdf/PAG_Advisory_Committee_Report.pdf

Rasberry, C. N., Tiu, G. F., Kann, L., McManus, T., Michael, S. L., Merlo, C. L., . . Ethier, K. A. (2017, September 8). Health-related behaviors and academic achievement among high school students - United States, 2015. Morbidity and Mortality Weekly Report, 66(35), 921-927. 